\title{
Gambaran Pola Gangguan Jiwa pada Pelaku Tindak Pidana Kekerasan yang Dimintakan Visum et Repertum Psikiatri ke RSJ Prof. HB. Saanin Padang Periode 1 Januari 2008 - 31 Desember 2012
}

\author{
Bikrulmal $^{1}$, Adnil Edwin Nurdin ${ }^{2}$, Rika Susanti ${ }^{3}$
}

\begin{abstract}
Abstrak
Beberapa jenis gangguan jiwa seperti disebutkan dalam berbagai literatur yang disokong oleh hasil penelitian, memiliki resiko untuk melakukan tindakan kekerasan. Hal ini merupakan masalah yang harus segera diatasi, mengingat besarnya kemungkinan bahwa peningkatan angka tindak kekerasan yang semakin bertambah dari hari ke hari. Tujuan penelitian ini adalah untuk mengetahui gambaran pola gangguan jiwa pada pelaku tindak pidana kekerasan yang dimintakan Visum et Repertum Psikiatri ke RSJ Prof. HB. Saanin Padang selama periode tahun 2008 - 2012. Metode penelitian yang digunakan adalah deskriptif retrospektif dan data yang diperoleh diolah secara manual dan disajikan dalam bentuk tabel distribusi frekuensi. Hasil penelitian menunjukkan terdapat 41 pelaku tindak pidana kekerasan yang dimintakan Visum et Repertum Psikiatri ke RSJ Prof. HB. Saanin Padang dengan jumlah bervariasi setiap tahunnya antara 4 sampai dengan 12 kasus. Sebagian besar pelaku dinilai menderita gangguan jiwa (75,6\%) dengan diagnosis gangguan jiwa paling banyak ditemukan adalah skizofrenia $(34,15 \%)$ khususnya skizofrenia paranoid (24,39\%). Sebanyak $49 \%$ pelaku dinilai tidak mampu menyadari tujuan dari perbuatan dan mengarahkan kemauan, terutama pada penderita skizofrenia (29,27\%).
\end{abstract}

Kata kunci: pola gangguan jiwa, tindak pidana kekerasan, visum et repertum psikiatri.

\section{Abstract}

Some specific types of mental disorders announced in the literature that supported by research data, show a risk to commit violent acts. This is a problem that must be overcome because the numbers of violence increase from day to day. The objective of this study was to describe the pattern of mental disorders in the violence criminal with Visum et Repertum Psychiatry requested to RSJ Prof. HB. Saanin Padang during the period 2008 - 2012. The research method used was a descriptive retrospective and the data obtained were processed manually and presented in the form of frequency distribution table. The results showed that during the period 2008 - 2012 there were 41 violent offenders who requested Visum et Repertum Psychiatry to RSJ Prof. HB. Saanin Padang with varying amounts each year between 4 to 12 cases. Most of the offenders assessed mental disorder (75.6\%) with a diagnosis of mental disorder most commonly found is schizophrenia (34.15\%), especially paranoid schizophrenia (24.39\%). 49\% of offenders were considered not able to realize the objectives of the action and directing the will, especially in patients with schizophrenia (29.27\%).

Keywords: patterns of mental disorders, violence criminal, visum et repertum psychiatry

Affiliasi penulis : 1. Pendidikan Dokter FK UNAND (Fakultas Kedokteran Universitas Andalas Padang), 2. Bagian Psikiatri FK UNAND/RSUP Dr. M. Djamil Padang, 3. Bagian Forensik FK UNAND/RSUP Dr. M. Djamil Padang.
Korespondensi : Bikrulmal, E-mail: bik@hotmail.co.id, Telp: 085668332080 


\section{PENDAHULUAN}

Salah satu problema sosial yang harus diperhatikan adalah munculnya tindak pidana kekerasan yang dilakukan oleh sebagian anggota masyarakat. Tindak pidana kekerasan adalah semua bentuk perilaku, baik verbal maupun non verbal, yang dilakukan oleh seseorang atau sekelompok orang, sehingga menyebabkan efek negatif secara fisik, emosional, atau psikologis terhadap orang yang menjadi sasaran. Undang-undang telah menetapkan tindak pidana sebagai suatu perbuatan yang harus dihukum. $^{1,2}$

Tindak pidana kekerasan menjadi salah satu faktor penting penyebab morbiditas dan mortalitas diantara individu usia muda 10 sampai 25 tahun, khususnya masyarakat kulit hitam dan laki-laki. Negara Amerika Serikat menempatkan tindak pidana kekerasan berupa pembunuhan sebagai penyebab kematian utama kedua pada kelompok usia 15 sampai 19 tahun. $^{3}$

Berdasarkan laporan Mabes Polri, jumlah tindak kriminal yang didalamnya termasuk laporan tindak pidana kekerasan selama periode tahun 2007 2009 di Indonesia yang meskipun berfluktuasi namun menunjukkan tren yang meningkat. Jumlah kejadian tindak kriminal dari sekitar 330.000 kasus pada tahun 2007 berkurang menjadi 327.000 pada tahun 2008 dan meningkat menjadi sekitar 345.000 pada tahun 2009. Di provinsi Sumatera Barat, tindak kriminal juga mengalami peningkatan. Angka tindak kriminal yang dilaporkan menurut Kepolisian Daerah/Polda Sumbar selama periode 2007-2009 berturut-turut adalah 9.499, 10.776, 11.848. ${ }^{4}$

Elbogen dan Johnson di tahun 2009, yang telah meneliti dengan menggunakan data longitudinal yang mewakili populasi Amerika Serikat menunjukkan bahwa insiden kekerasan lebih tinggi pada orang dengan gangguan mental berat seperti skizofrenia, gangguan bipolar, dan depresi berat. ${ }^{6} \mathrm{Di}$ Indonesia sendiri, belum ditemukan adanya laporan penelitian terkait pola gangguan jiwa pada pelaku tindak pidana kekerasan secara nasional.

Berdasarkan beberapa penelitian tersebut, maka besar kemungkinan meningkatnya angka tindak pidana kekerasan saat ini merupakan kontribusi dari penderita gangguan jiwa. Negara Indonesia, berdasarkan peraturan perundang-undangan yang berlaku, perlakuan terhadap pelaku tindak pidana kekerasan yang dilakukan oleh penderita gangguan jiwa berbeda dengan peraturan yang ditetapkan untuk pelaku tindak pidana tanpa gangguan jiwa. Untuk itu diperlukan keterangan tertulis yang dibuat oleh Dokter Spesialis Kedokteran Jiwa atas permintaan penyidik yang berwenang mengenai hasil pemeriksaan terhadap manusia mengenai jiwa atau mental tersangka atau terdakwa tindak pidana yang disebut Visum et Repertum Psikiatri (VeRP).

Ditinjau dari pemanfaatan keterangan ahli sebagai alat bukti yang sah dalam pengambilan keputusan hukum di Indonesia, kasus pidana merupakan kasus hukum yang paling sering dimintakan pembuatan VeRP. Meskipun demikian, tidak semua kasus pidana dimintakan VeRP. VeRP diterbitkan hanya atas suatu permintaan dan yang berhak meminta berdasarkan peraturan perundangundangan adalah hakim, jaksa, dan polisi. Biasanya permintaan VeRP baru dilakukan apabila yang berwenang memiliki dugaan bahwa tersangka memiliki gangguan jiwa. Dugaan tersebut berdasarkan adanya sikap atau tingkah laku yang memberikan kesan tidak normal pada tersangka. Mengingat penilaian normal atau tidaknya seseorang bukanlah hal yang mudah, maka besar kemungkinan terjadi kekeliruan dalam menentukan seseorang pantas atau tidak dimintakan keterangan psikiatri serta menyebabkan perbandingan jumlah permintaan VeRP dengan jumlah keputusan terhadap kasus hukum pidana kekerasan bervariasi di setiap daerah sehingga menimbulkan kesan keadilan di seluruh daerah di Indonesia tidaklah seragam. ${ }^{7}$

Penelitian ini bertujuan untuk mengetahui pola gangguan jiwa pada pelaku tindak pidana kekerasan di Sumatera Barat berdasarkan hasil VeRP yang dimintakan ke RSJ Prof. HB. Saanin Padang.

\section{METODE}

Jenis penelitian yang digunakan adalah penelitian deskriptif retrospektif. Penelitian ini dilakukan di RSJ Prof. HB. Saanin Padang dari Maret 2013 - April 2013. Populasi penelitian adalah seluruh pelaku tindak pidana kekerasan yang dimintakan VeRP ke RSJ Prof. HB. Saanin Padang selama periode 1 Januari 2008 - 31 Desember 2012. 
HASIL

Distribusi jumlah pelaku tindak pidana kekerasan yang dimintakan VeRP ke RSJ Prof. HB. Saanin Padang dapat dilihat pada Tabel 1 di bawah ini:

Tabel 1. Distribusi jumlah pelaku tindak pidana kekerasan yang dimintakan VeRP ke RSJ Prof. HB. Saanin Padang pertahun periode penelitian

\begin{tabular}{cccc}
\hline No & Tahun & \multicolumn{2}{c}{$\begin{array}{c}\text { VeRP yang Dimintakan } \\
\text { Jumlah }\end{array}$} \\
\hline 1 & 2008 & 7 & 17,1 \\
2 & 2009 & 4 & 9,7 \\
3 & 2010 & 12 & 29,3 \\
4 & 2011 & 8 & 19,5 \\
5 & 2012 & 10 & 24,4 \\
\hline
\end{tabular}

Tabel 1 memperlihatkan bahwa selama kurun waktu 5 tahun, antara 1 Januari 2008 - 31 Desember 2012, terdapat 41 kasus yang dimintakan VeRP ke RSJ Prof. HB. Saanin Padang. Jumlah kasus tersebut bervariasi setiap tahunnya, antara 4 sampai dengan 12 kasus. Rerata kasus yang dimintakan VeRPnya pertahun adalah 8 kasus. VeRP terbanyak dimintakan pada tahun 2010 yaitu 12 kasus.

Distribusi pelaku tindak pidana kekerasan yang dimintakan VeRP ke RSJ Prof. HB. Saanin Padang menurut diagnosis psikiatri sesuai dengan PPDGJ III dapat dilihat pada Tabel 2.

Tabel 2. Distribusi pelaku tindak pidana kekerasan yang dimintakan VeRP ke RSJ Prof. HB. Saanin Padang menurut diagnosis psikiatri sesuai dengan PPDGJ III

\begin{tabular}{ccc}
\hline No & Diagnosis Psikiartri & \multicolumn{2}{c}{$\begin{array}{c}\text { Pelaku Tindak } \\
\text { Pidana Kekerasan } \\
\text { Jumlah }\end{array}$} \\
\hline $1 \quad$ F00 - F09 Gangguan Mental Organik \\
F07 Gangguan kepribadian \\
dan perilaku akibat penyakit, \\
kerusakan, dan disfungsi otak \\
F11 Gangguan Mental dan Perilaku \\
Akibat Penggunaan Opioida \\
F11.02 Gangguan mental \\
dan perilaku akibat \\
penggunaan opioda, \\
intoksikasi akut dengan \\
komplikasi medis lainnya
\end{tabular}

$3 \quad$ F20 Skizofrenia

$\begin{array}{lcc}\text { F20.0 Skizofrenia paranoid } & 10 & 24,39 \\ \text { F20.5 Skizofrenia residual } & 2 & 4,87 \\ \text { F20.8 Skizofrenia lainnya } & 1 & 2,44 \\ \text { F20.9 Skizofrenia YTT } & 1 & 2,44\end{array}$

$4 \quad$ F23 Gangguan Psikotik Akut dan Sementara

F23.2Gangguan psikotik

lirskizofrenia (schizophrenia

like) akut

$5 \quad$ F31 Gangguan Afektif Bipolar

F31.2 Gangguan afektif bipolar, episode kini manik

dengan gejala psikotik

F31.6 Gangguan afektif

bipolar, episode kini

campuran

F31.7 Gangguan aafektif

bipolar, kini dalam remisi

$6 \quad$ F32 Episode Depresif

F32.0 Episode depresif

ringan

F32.1 Episode depresif

sedang

F32.3 Episode depresif

berat dengan gejala psikotik

F32.9 Episode depresif YTT

,39

44

2,44

7 F70 - F79 Retardasi Mental
F71 Retardasi menta

7 F70 - F79 Retardasi Mental
F71 Retardasi mental

sedang

F79 Retardasi Mental YTT

8 Tidak ada kelainan

Jumlah

2,44

2,44

4,87

2,44

2,44

24,39

$\begin{array}{lc}10 & 24,39 \\ 41 & 100\end{array}$

Tabel 2 menunjukkan bahwa sebagian besar, yaitu 31 kasus $(75,6 \%)$, pelaku pidana yang dimintakan VeRP menderita gangguan jiwa. Sisanya bejumlah 10 orang $(24,39 \%)$ dinyatakan tidak memiliki gangguan jiwa. Kategori diagnosis yang terbanyak ditemukan adalah skizofrenia, yaitu sebanyak 14 kasus (34.15\%). Dari katergori tersebut, jenis terbanyak dijumpai adalah skizofrenia paraniod (F20.0) yaitu sebanyak 10 kasus (24,39\%).

Distribusi kemampuan pelaku tindak pidana kekerasan yang dimintakan VeRP ke RSJ Prof. HB. Saanin Padang berdasarkan kemampuan menyadari tujuan dari suatu perbuatan dan mengarahkan kemauan menurut diagnosis psikiatrinya dapat dilihat pada Tabel 3 dibawah ini : 
Tabel 3. Distribusi kemampuan pelaku tindak pidana kekerasan yang dimintakan veRP ke RSJ Prof. HB. Saanin Padang menyadari tujuan dari suatu perbuatan dan mengarahkan kemauan menurut kategori diagnosis psikiatrinya

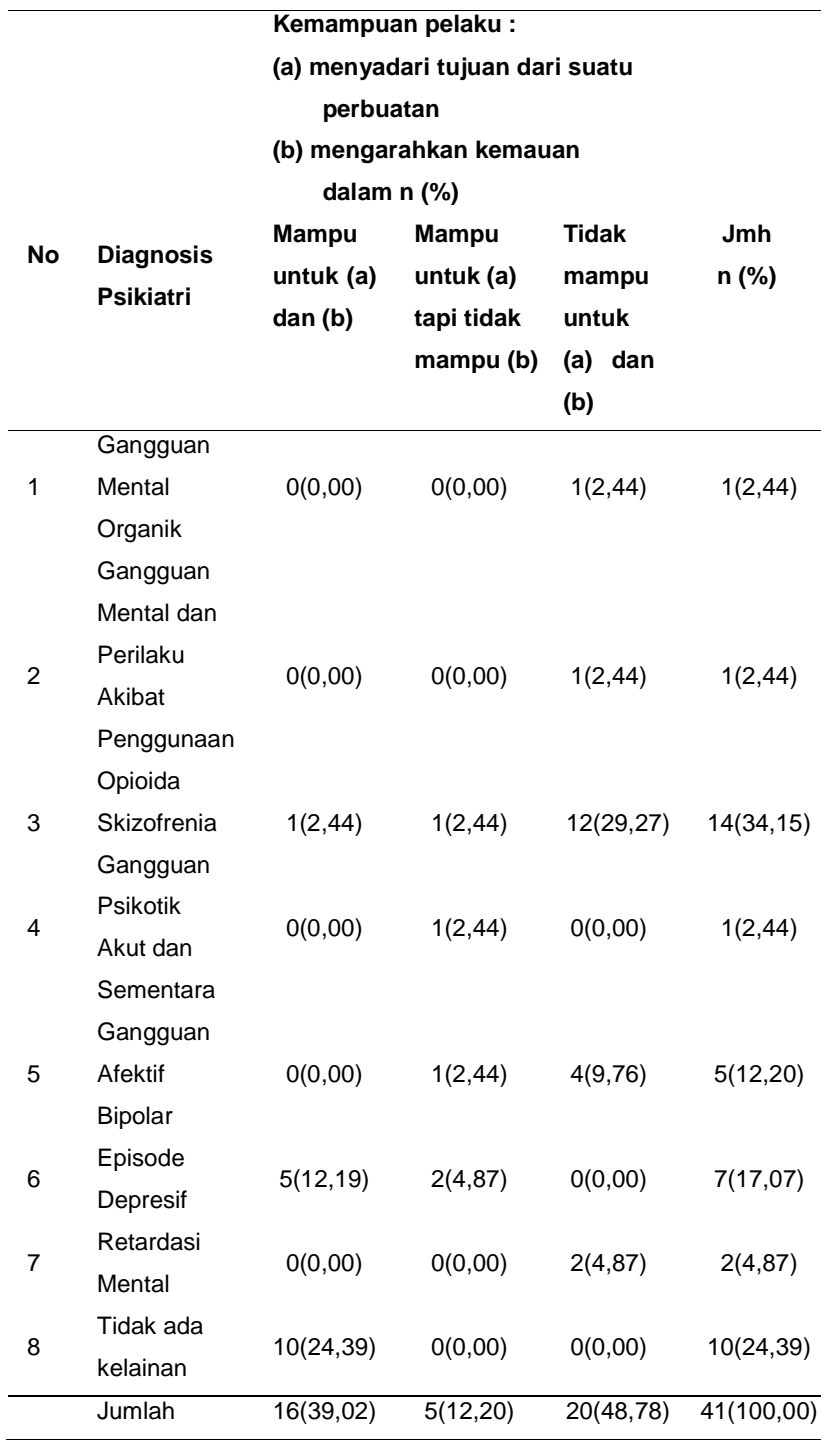

Pada tabel 3, terlihat bahwa 20 pelaku dinilai tidak mampu menyadari sifat dan perbuatannya serta tidak mampu mengarahkan kemauannya. Keadaan ini paling banyak ditemukan pada pelaku yang didiagnosis menderita skizofrenia (12 orang atau $29,27 \%)$. 5 pelaku (12,20\%) lainnya dinilai mampu menyadari perbuatannya tetapi tidak mampu mengarahkan kemauannya. Sisanya, sebanyak 16 pelaku $(39,02 \%)$ dinilai mampu menyadari perbuatan serta mampu mengarahkan kemauannya.

\section{PEMBAHASAN}

Selama periode tahun 2008 sampai dengan tahun 2012 ditemukan sebanyak 41 VeRP yang dimintakan ke RSJ Prof. HB. Saanin Padang oleh pihak yang berwenang. Tabel 1 menunjukkan bahwa permintaan VeRP ke RSJ Prof. HB. Saanin Padang berfluktuasi tiap tahunnya. Tercatat 7 kasus pada tahun 2008, kemudian menurun menjadi 4 kasus pada tahun 2009, berikutnya meningkat lagi pada tahun 2010 menjadi 12 kasus, pada 2011 menurun lagi menjadi 8 kasus, dan meningkat lagi menjadi 10 kasus pada tahun 2012. Angka ini tidak dapat digunakan sebagai cerminan kejadian tindak pidana kekerasan di Sumatera Barat yang dilakukan oleh penderita gangguan jiwa setiap tahunnya, sebab tidak semua pelaku tindak pidana dilakukan pemeriksaan psikiatri. Pemeriksaan psikiatri hanya apabila penyidik memintakan VeRP pelaku pidana yang diduga mengalami gangguan jiwa ke RSJ. Dengan kata lain, indikasi permintaan pemeriksaan pelaku pidana sangat bergantung pada kejelian dan ketepatan seorang penilai yang bukan dokter.

Pada Tabel 2 dapat dilihat bahwa 80,5\% (33 kasus) dari seluruh pelaku tindak pidana kekerasan (41 kasus) yang dimintakan VeRP ke RSJ Prof. HB. Saanin Padang periode 2008 - 2012 dinyatakan positif mengalami gangguan jiwa. Kategori diagnosis yang paling banyak ditemukan adalah skizofrenia, yaitu sebanyak 14 kasus (34,15\%). Adanya gejala-gejala khas pada penderita skizofrenia seperti waham dan halusinasi terutama halusinasi auditorik memungkinkan perilaku kekerasan yang dilakukan oleh penderita merupakan respon penderita terhadap gejala-gejala tersebut. Dari kategori skizofrenia, skizofrenia paranoid (F20.0) merupakan subtipe yang paling banyak ditemukan, yaitu berjumlah 10 kasus $(24,39 \%)$. Skizofrenia paranoid memang merupakan subtipe yang paling sering dijumpai di setiap negara. Episode depresif dan gangguan afektif bipolar secara berturut-turut menempati peringkat ke 2 dan ke 3 kategori diagnosis terbanyak, yakni 7 kasus $(17,07 \%)$ dan 5 kasus $(12,20 \%)$.

Tabel 3 mempelihatkan bahwa 48,78\% dari pelaku tindak pidana yang dimintakan VeRP dinilai tidak mampu menyadari perbuatan dan mengarahkan kemauannya. Sebagian besar penilaian ini ditemukan pada pasien skizofrenia $(29,27 \%)$, kemudian disusul dengan gangguan afektif bipolar $(9,76 \%)$, retardasi 
mental $(4,87 \%)$, gangguan mental organik $(2,44 \%)$ dan gangguan mental dan perilaku akibat penggunaan opioida (2,44\%). $12,20 \%$ pelaku lainnya dinilai mampu menyadari perbuatannya namun tidak mampu memilih dan mengarahkan kemauannya. Sisanya, 39,02\% pelaku dinilai mampu menyadari perbuatannya dan mampu mengarahkan kemauannya. Pelaku yang memiliki kemampuan untuk menyadari perbuatan dan mengarahkan kemauannya tidak hanya ditemukan pada pelaku yang didiagnosis tidak memiliki gangguan jiwa, namun penilaian ini juga ditemukan pada pelaku dengan diagnosis skizofrenia dan episode depresif. Hal ini menunjukkan bahwa tidak selalu perilaku kekerasan merupakan bagian atau gejala dari gangguan jiwa. ${ }^{7}$

\section{KESIMPULAN}

Selama periode tahun 2008 - tahun 2012, permintaan VeRP pada pelaku tindak pidana kekerasan ke RSJ Prof. HB. Saanin Padang tertinggi ditemukan pada tahun 2010.

Sebagian besar didiagnosis menderita gangguan jiwa sebagai berikut :

1. Gangguan mental organik.

2. Gangguan mental dan perilaku akibat penggunaan opioida.

3. Skizofrenia.

4. Gangguan psikotik akut dan sementara.

5. Gangguan afektif bipolar.

6. Episode depresif.

7. Retardasi mental.

Skizofrenia merupakan diagnosis yang paling banyak ditemukan pada pelaku tindak pidana kekerasan yang dimintakan VeRP ke RSJ Prof. HB. Saanin Padang periode 2008 - 2012.

Sebagian besar pelaku tindak pidana kekerasan yang didiagnosis mengalami gangguan jiwa dinilai tidak mampu menyadari perbuatannya dan tidak mampu mengarahkan kemauannya.

Kepolisian khususnya penyidik telah menunjukkan kinerjanya dalam menentukan dugaan terhadap pelaku tindak pidana kekerasan yang memiliki gangguan jiwa dengan baik, sebab lebih dari dua pertiga pelaku $(75,6 \%)$ yang dimintakan VeRP didiagnosis menderita gangguan jiwa.

\section{DAFTAR PUSTAKA}

1. Budiayanto Arif, Widiatmaka W, Sudiono S, Winardi T, Mun'im A, Sidhi, et al. IImu kedokteran forensik. Jakarta: Bagian Kedokteran Forensik Fakultas Kedokteran Universitas Indonesia;1997.

2. Muljono W. Pengantar teori kriminologi. Yogyakarta: Penerbit Pustaka Yustisia; 2012.

3. Wong $\mathrm{DL}$, Eaton $\mathrm{MH}$, Wilson $\mathrm{D}$, Winkelstein $\mathrm{ML}$, Schwartz $\mathrm{P}$. Wong's essential of pediatric nursing. Dalam: Agus S, Juniarti, N, Kuncara, HY, penerjemah. Buku Ajar Keperawatan Pediatrik Wong, Edisi ke-6, Volume 1. Jakarta: EGC; 2008.

4. Badan Pusat Statistik. Statistik kriminal 2007 2009. Jakarta: Badan Pusat Statistik; 2010.

5. Kaplan HI, Sadock BJ, Grebb JA. Synopsis of psychiatry. Edisi ke-7. Kusuma W, penerjemah. Sinopsis Psikiatri, IImu Pengetahuan Perilaku Psikiatri klinis. 1997, Jilid 1. Jakarta: Binapura Aksara; 2010.

6. Elbogen EB, Johnson SC, The intricate link beetween violence and mental disorder. result from the national epidemiologic survey on alcohol and related condition (diunduh 11 Januari 2013) Tersedia dari: URL: HYPERLINK http://archpsyc. jamanetwork.com/journal.aspx

7. Darmabrata W, Nurhidayat AW. Psikiatri Forensik. Jakarta: EGC; 2003. 